Swarthmore College

Works

$4-1-1990$

\title{
A Comparison Of Radar Observations Of Bird Migration At Haizhou Bay, China, And Guam, Marianas
}

Timothy C. Williams , '64

Swarthmore College, twillia1@swarthmore.edu

M. Ying

Follow this and additional works at: https://works.swarthmore.edu/fac-biology

Part of the Biology Commons

Let us know how access to these works benefits you

\section{Recommended Citation}

Timothy C. Williams , '64 and M. Ying. (1990). "A Comparison Of Radar Observations Of Bird Migration At Haizhou Bay, China, And Guam, Marianas". Auk. Volume 107, Issue 2. 404-406.

https://works.swarthmore.edu/fac-biology/253

This work is brought to you for free by Swarthmore College Libraries' Works. It has been accepted for inclusion in Biology Faculty Works by an authorized administrator of Works. For more information, please contact myworks@swarthmore.edu. 
A Comparison of Radar Observations of Bird Migration at Haizhou Bay, China, and Guam, Marianas

Author(s): Timothy C. Williams and Mao Ying

Source: The Auk, Vol. 107, No. 2 (Apr., 1990), pp. 404-406

Published by: American Ornithologists' Union

Stable URL: http://www.jstor.org/stable/4087627

Accessed: 27-04-2015 14:47 UTC

\section{REFERENCES}

Linked references are available on JSTOR for this article:

http://www.jstor.org/stable/4087627?seq=1\&cid=pdf-reference\#references_tab_contents

You may need to log in to JSTOR to access the linked references.

Your use of the JSTOR archive indicates your acceptance of the Terms \& Conditions of Use, available at http://www.jstor.org/page/info/about/policies/terms.jsp

JSTOR is a not-for-profit service that helps scholars, researchers, and students discover, use, and build upon a wide range of content in a trusted digital archive. We use information technology and tools to increase productivity and facilitate new forms of scholarship. For more information about JSTOR, please contact support@jstor.org. 


\title{
A Comparison of Radar Observations of Bird Migration at Haizhou Bay, China, and Guam, Marianas
}

\author{
Timothy C. WILliams ${ }^{1}$ and MaO YING ${ }^{2}$ \\ ${ }^{1}$ Swarthmore College, Swarthmore, Pennsylvania 19081 USA, and \\ ${ }^{2}$ Department of Biology, Shanghai Second Medical University, 280 South Chongqing Road, \\ Shanghai, People's Republic of China
}

During September and October of 1983 we made simultaneous radar studies at Haizhou Bay on the east coast of China and on Guam in the Mariana Islands (Mao MS, 1985; Mao and Zhou 1987; Williams and Williams 1988). Neither investigator was aware of the other's work. In this report we compare the observations to clarify autumnal migration patterns in the Western Pacific and the eastern coast of Asia. We know of no other radar studies of autumnal migration in this area. (Myres and Apps [1973] detected migration over Hong Kong, moving toward the southwest over the China Sea in September and October, but they gave no details.)

Both studies used high power, $10-\mathrm{cm}$ radars operated at 93-km range. Two $450 \mathrm{~kW}$ coastal surveillance radars were used at Haizhou Bay, at Cheniushan Island $\left(34^{\circ} 59^{\prime} \mathrm{N}, 119^{\circ} 49^{\prime} \mathrm{E}\right.$, elevation $\left.67 \mathrm{~m}\right)$ and Yuntai Mountain $\left(34^{\circ} 4^{\prime} \mathrm{N}, 119^{\circ} 27^{\prime} \mathrm{E}\right.$, elevation $\left.625 \mathrm{~m}\right)$. The majority of the work was performed at Yuntai Mountain. The instruments had relatively narrow beams (values not available to the authors) and did not use MTI. Data were taken by direct observation of the radar display. Mao and two radar operators observed radar displays continuously from 3 September through 5 November except on 5-11, 13, and 16 September. Speed and direction of movement were computed directly from measurements made of 556 echoes on the radar Plan Position Indicator (PPI) and the radar B scope. Density of migration was determined by counting the number of echoes within 93-km range on the PPI or (for heavy migrations) by counting the numbers on the B scope (see Eastwood 1967) and estimating the totals for the entire screen. The maximum estimate for a given period was converted to a logarithmic density scale of 1-5 (1 indicates less than 20 echoes on the PPI at one time, $2=21-100,3=$ $101-200,4=201-500$, and $5=$ more than 500 echoes).

A 1 MW FPS 93 alpha air surveillance radar (broad horizontal beam width, value not available to authors) was used with MTI at Andersen Air Force Base, Guam $\left(13^{\circ} 25^{\prime} \mathrm{N}, 144^{\circ} 45^{\prime} \mathrm{E}\right.$, elevation $\left.30 \mathrm{~m}\right)$. Radar observations were made at least 4 times daily for periods of $1 \mathrm{~h}$ with $8-\mathrm{mm}$ time-lapse cinematography and once daily for ca. 15 min using time exposures (Williams 1988). Speed and direction of birds were computed from individual tracks on the photographs.

Track and ground speed refer to the velocity of a bird relative to the ground. Heading and airspeed refer to the velocity of a bird relative to the air mass in which it flies. The mean vector is used to describe circular normal distributions and consists of a direction and a length, $r$, which is a measure of dispersion and varies from 0 (no central tendency) to 1 (no dispersion) (Batschelet 1981). Chi-square tests were used for comparing data samples that departed from the circular normal distribution (Batschelet 1981).

Haizhou Bay and Guam had different periods of maximum migratory activity. Radar observations in Guam had a peak in detected echoes during early September, a decrease in the last week of September, and a second, less pronounced peak in October (Fig. 1). Activity at Haizhou Bay was heavy by mid-September with a peak of maximum migration density in early October.

The density of bird migration was less over Guam than over China. At Guam the largest number of bird echoes detected within a 93-km range at one time was 13. At Haizhou Bay, 40-50 bird echoes were often detected simultaneously within the same range, and the greatest number exceeded 600. Although Richardson (1972) cautions against precise comparisons of migration density at different radars, the higher density over China was recorded with a lower power, more narrow beam radar than was used in Guam. Williams and Williams (1988) estimated that perhaps half a million shorebirds fly within $1,000 \mathrm{~km}$ of Guam each autumn while Mao (MS) estimated that 10 million birds pass over Haizhou Bay alone.

Over Haizhou Bay, the great majority of birds moved to the southwest and south-southwest parallel to the general line of the Asian coast (Fig. 2). A much smaller number of birds moved southeast over the sea. When these movements were separated from the total, we found that both the density and seasonality of southeast movements were closer to the values for Guam than were the southwest migrations. Southeast movements showed a maximum density of 2 on the logarithmic scale of $1-5$, and these maxima were more common in September (33\% of total southeast migrations) than in October (19\%).

Southwest migrants at Haizhou Bay were influenced strongly by local factors such as time of day and weather, but southeast migrants at Haizhou Bay and migrants at Guam were unaffected by local weather or time of day. Mao (MS) found that total autumnal migration density was correlated significantly with falling temperatures, following winds (north and northeast), and synoptic weather. Mao and Zhou (1987) report significant differences for density of diurnal and nocturnal migrations. Unlike the southwest migrations, neither diurnal nor nocturnal southeast migration densities were associated signif- 

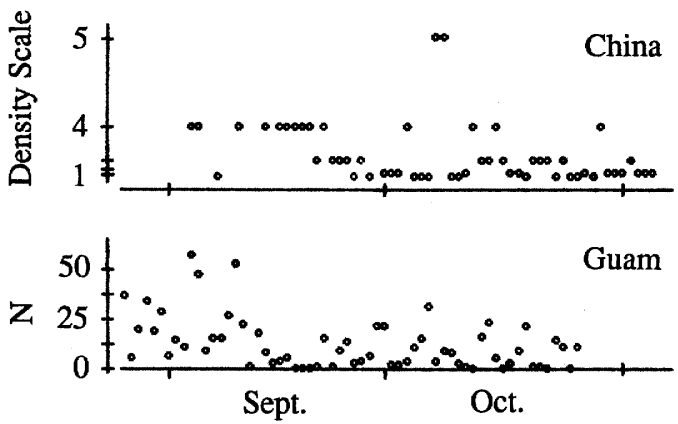

Date

Fig. 1. Migratory activity as detected by radar at Haizhou Bay, China, and Guam, Mariana Islands, autumn 1983. In China, maximum daily density for all migration directions was scored on a logarithmic scale from 1 to 5 (see text). The total number of radar echoes detected in ca. $4 \mathrm{~h} /$ day of observation is plotted for Guam.

icantly with wind direction $\left(P>0.05, \chi^{2}<12\right)$. At Haizhou Bay diurnal (mean vector $=224^{\circ}, r=0.696$ ) and nocturnal (mean vector $=204^{\circ}, r=0.752$ ) distributions of direction for all birds were significantly different $\left(P<0.0001, \chi^{2}=53\right)$. At Guam there was no significant difference in direction over time of day (Williams and Williams 1988). Track directions over Guam (mean vector $=185^{\circ}, \mathrm{r}=0.92$ ) differed significantly from both diurnal and nocturnal track directions at Haizhou Bay $\left(P<0.0001, \chi^{2}>100\right)$. Tracks for the southeast migrants at Haizhou could not be tested as they were selected on the basis of direction.

Ground speed and characteristics of the radar echo indicate that birds that move southeast (away from the coast of China) and birds over Guam are primarily shorebirds, whereas the route parallel to the coast is used by several taxa including passerines. The mean ground speed of migrants was $61.2 \mathrm{~km} / \mathrm{h}(17.0 \mathrm{~m} / \mathrm{s})$ at Haizhou Bay and $60.7 \mathrm{~km} / \mathrm{h}(16.9 \mathrm{~m} / \mathrm{s})$ at Guam. Birds that moved southeast at Haizhou Bay and birds over Guam usually flew in crosswinds, and thus their airspeeds would be similar to their ground speeds. Birds that moved southwest at Haizhou Bay usually flew with favorable winds, and thus their airspeeds would be less than their ground speeds (Mao and Zhou 1987). All migrants at Guam, southeast migrants at Haizhou Bay, and the great majority of southwest migrants at Haizhou Bay gave bright, coherent echoes of the type previously identified with shorebirds in Europe and North America (Richardson 1979, Williams 1985). At Haizhou Bay the radar observers also detected echoes indicative of southwest passerine migration. These were either small, less coherent echoes with an average ground speed of $44.4 \mathrm{~km} / \mathrm{h}(12.3 \mathrm{~m} /$ s) or were the noncoherent, scintillating echoes identified as passerines in Europe and North America

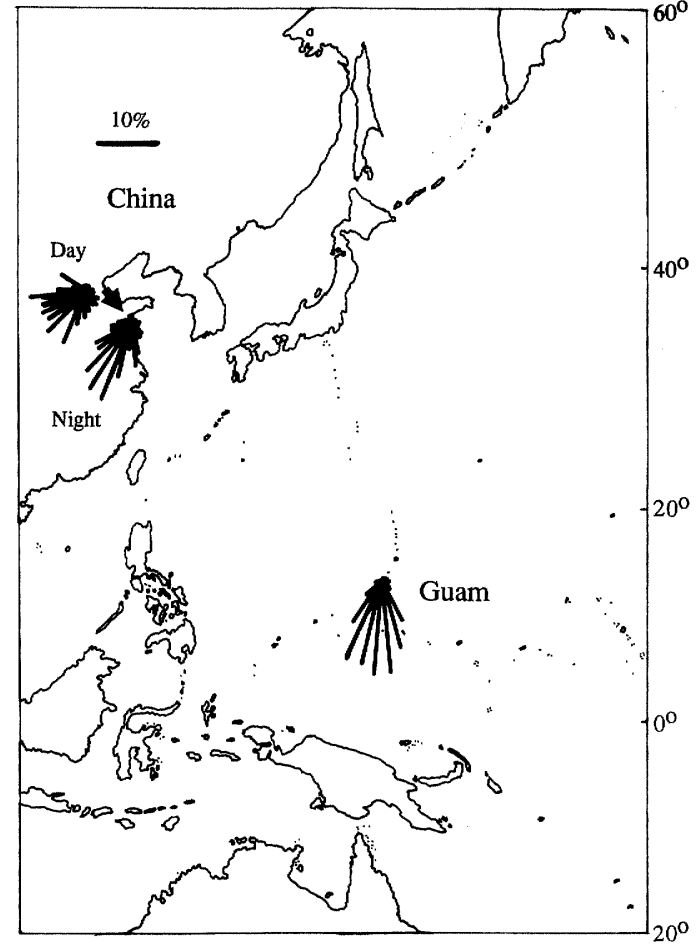

Fig. 2. Circular histograms of daily average track direction as detected by radars at two sites. The histogram for Guam shows the distribution of 766 echoes detected at Andersen Air Force Base during the autumn of 1983. The two upper histograms give the distribution of 556 tracks scored for direction at Haizhou Bay, China. Nocturnal observations are centered on the observation site; diurnal observations are offset for clarity, but were made at the same location.

(Eastwood 1967). The small echoes were rare, and the scintillating echoes could not be tracked on the PPI display and are not included in the data. Even at high density, passerine echoes did not prevent measurements of bright echoes on the $B$ scope.

Seasonal species distribution and banding studies in eastern Asia and the western Pacific support our conclusions from the radar data: shorebirds depart the coast on a transpacific flight to southern Pacific islands and Australia while larger numbers of many taxa move southwest along the Asian coast (McClure 1974; $X u$ and Purchase 1983; Pyle and Engbring 1985, 1987; Williams and Grout 1985; Lane and Jessop 1985; Cheng 1987; Lane 1987; Parish et al. 1987).

To test whether migratory activity at Guam was preceded by heavy migratory activity on the east China coast, we compared the number of birds detected per day at Guam with the density scale of the same day and 24,48 , and $72 \mathrm{~h}$ earlier. (An exponential trans- 
form was used to render the density scale linear.) We tested both total migratory activity and density of southeast migrants at Haizhou Bay. Neither regression nor rank correlation gave significant associations at $P<0.05$ for either. The densest migrations recorded over Guam were excluded from these tests because observations at Haizhou Bay were not continuous in early September. The lack of temporal association between migratory activity at Haizhou Bay and at Guam may reflect insufficient data or may indicate that birds that move over Guam depart the Asian coast well east of Haizhou Bay (see Fig. 2).

Many features of the migration routes in the western North Pacific are similar to those in the western North Atlantic (Williams et al. 1977, Richardson 1980, Williams 1985). In both cases a large number of birds move southwest along the general coastline, while a smaller number move south to southeast flying thousands of kilometers from land. Coastal migrants are strongly affected by local conditions, whereas transoceanic migrants appear to maintain constant compass headings without regard to local conditions (Williams 1985, Williams and Williams 1988). The principal differences appear to be that both seasonality of migration and airspeeds indicate that large numbers of passerines make flights over the Atlantic, but only shorebirds appear to use the route over the Pacific.

We thank all officers for permission to use the radars at Haizhou Bay. Hu Anyu and Li Zhuoming helped collect data. Professor Zhou Benxiang assisted in all areas of the research in China; Professors Chien Kuo-chen, Xu Weishu, Sen Heling, and Wang Qishen also made helpful suggestions. P. Grout assisted in collection and scoring of data at Guam. We thank W. Cannon, FAA, and Colonel D. Moorhous, USAF, for permission to use radar facilities on Guam. J. M. Williams and $\mathrm{W}$. J. Richardson made helpful comments on the manuscript. This research was supported by the East China Normal University, the National Science Foundation (BNS 8309823), Research Corporation, the Explorers Club, Swarthmore College Faculty Research Fund, and Swarthmore College.

\section{LITERATURE CITED}

Batschelet, E. 1981. Circular statistics in biology. New York, Academic Press.

ChEng Tso-HSIN. 1987. A synopsis of the avifauna of China. Berlin, Beijing, Parey, Science Press.

EASTwOOD, E. 1967. Radar ornithology. London, Methuen.

LANE, B. 1987. Shorebirds in Australia. Melbourne, Nelsons.
LANE, B. \& A. JESSOP. 1985. Tracking of migrating waders in north-western Australia using meteorological radar. Stilt 6: 17-28.

MAO YING. 1985. Wader migration in Haizhou Bay eastern China. Interwader Newsletter 6: 10-11.

-, \& ZHOU BENXIANG. 1987. [Observations on bird migration by radar in Haizhou Bay]. Acta Zool. Sinica 33: 277-284. (English summary.)

MCCluRE, H. E. 1974. Migration and survival of the birds of Asia. Bangkok, Thailand, U.S. Army Med. Comp., SEATO Med. Proj.

MYRES, M. T., \& R. F. APPS. 1973. Migration of birds over the south coast of China recorded by radar. Nature 241: 552.

PARISH, D., B. LANE, P. SAGaR, \& P. TOMKovitch. 1987. Wader migration systems in east Asia and Australia. Wader Study Group Bull. 49: Supplement. IWRB Spec. Publ. 7: 4-14.

Pyle, P., \& J. ENGBRING. 1985. Checklist of the birds of Micronesia. 'Elepaio 46: 57-68.

$\longrightarrow, \&-$ 1987. New bird records and migrant observations from Micronesia 1977-1984. 'Elepaio 47: 11-15.

RICHARDSON, W. J. 1972. Temporal variations in the ability of individual radars in detecting birds. Field Note 6. Ottawa, Associate Committee on Bird Hazards to Aircraft, Natl. Res. Council.

—. 1979. Southeastward shorebird migration over Nova Scotia and New Brunswick in autumn: a radar study. Can. J. Zool. 57: 107-124.

- 1980. Autumn landbird migration over the western Atlantic Ocean as evident from radar. Proc. 17th Int. Ornithol. Congr. Berlin 1978: 501506.

Williams, J. M., \& P. C. Grout. 1985. Migrants on Guam, Fall 1983. 'Elepaio 46: 41-44.

Williams, T. C. 1985. Autumnal bird migration over the windward Caribbean Islands. Auk 102: 163167.

—. 1988. Bias in radar data recording techniques. J. Field Ornithol. 59: 63-66.

—, \& J. M. Williams. 1988. Radar and visual observations of autumnal (southward) bird migration at Guam. Auk 105: 460-466.

,$- \longrightarrow$, L. C. Ireland, \& J. M. Teal. 1977. Bird migration over the western North Atlantic Ocean. Am. Birds 31: 251-267.

Xu Weishu, \& D. Purchase. 1983. On the migration of banded waders between China and Australia. Mem. Beijing Nat. Hist. Mus. 23: 1-12.

Received 21 November 1988, accepted 20 September 1989. 